\title{
Conceptual Foundations of Inclusive Systems in and around Schools for Early School Leaving Prevention: An Emotional-Relational Focus
}

\author{
Paul Downes ${ }^{1}$ \\ Institute of Education, Dublin City University
}

Against the background of the EU2020 headline target of reducing early school leaving to $10 \%$ across Europe, this article examines the conceptual foundations of the understanding of inclusive systems for early school leaving prevention that has emerged in EU policy documents and research reports in recent years. Traditionally, inclusive education has referred to a focus on children with special educational needs. However, this conceptual review examines how inclusion is increasingly being examined in broader terms. This review seeks to critically reconstruct foundational understandings of systems and resilience in developmental and educational psychology. A systems focus on inclusion needs to address the neglect in psychology of system blockages and power imbalances. Resilience is typically framed as the capacity of the individual to navigate their way to environmental resources. This places the onus of accessibility onto the individual's efforts rather than a concern with responsive systems accessible to marginalised groups. A concern with inclusive systems goes beyond not only the well-established framework of individual resilience in developmental psychology, but also beyond its expansion into resilient systems, as these omit a focus on outreach and multidisciplinary teams in systems of care for integrated services. Common principles for a framework of inclusive systems include children's voices, equality and non-discrimination, parental involvement that is integrated holistically with family support, and lifelong learning principles for schools. Illustrative examples of

1 Dr. Paul Downes, Director, Educational Disadvantage Centre, Senior Lecturer in Psychology, Institute of Education, Dublin City University paul.downes@dcu.ie has been an advisor to successive European Commission Thematic and School Policy Working Groups on Early School Leaving. This text is based on his opening keynote presentation Developing inclusive systems in and around schools for early school leaving prevention: The importance of emotions and relationships, at the Serbian Ministry of Education, Science and Technological Development, UNICEF and the Centre for Education Policy in Serbia Conference, "Combating Early School Leaving in Serbia through effective dropout prevention and intervention measures at the school level", 28-29 November 2016, Belgrade. 
these principles for reforming authoritarian teaching and discriminatory bullying, for opening schools to the local community and for targeting those with highest levels of need are highlighted.

Key words: Inclusive Systems, Early School Leaving, Resilience, Bullying

A significant, though somewhat overlooked, shift in conceptualisation has taken place in education and educational psychology in recent years with regard to inclusion. Traditionally, inclusive education has referred to a focus on children with special educational needs (Kyriazopoulou\& Weber, 2009). However, educational inclusion is increasingly being examined in broader terms. For example, the UNESCO (2016) report on supporting inclusive education explicitly recognises that inclusion involves a particular emphasis on those groups of learners who may be at risk of marginalisation, exclusion or underachievement. The United Nation's Sustainable Development Goal 4 aims to ensure inclusive and equitable quality education, and promote lifelong learning opportunities for all by 2030 .The need to engage marginalized voices in education systems is further amplified in the UNESCO (2016) report on supporting inclusive education:

... representation tends to be dominated by the most outspoken and articulate groups. This can result in consultation exercises, which, although intended to be inclusive, actually reinforce a sense of exclusion and disaffection among some of the school community. (p.81)

There is an increasing focus not only on power relations in school as a dimension of inclusion, such as with regard to discriminatory bullying (Elamé, 2013), but also on schools as inclusive systems.

Almost five decades ago, the seminal UNESCO Faurereport on lifelong learning (1972) touched upon the potential relevance of a systems analysis for education systems (p.128, p.161). However, it did so in an underdeveloped way through concerns with static conceptions of a system and highlighted the need to consider not so much a systemic approach but rather an inverted, diametrically opposite non-system approach for education (p.161). This deschooling non-systemic approach, presumably influenced by Illich's (1971) famous work on deschooling society, understates the need to recognise that even attempts at a non-systemic approach invariably develop simply a different kind of system of relations requiring analysis. Systems of relations need to be considered at different levels, including those of language, culture and also intrapsychic processes as systems (Downes, 2012) and to ignore a systemic level focus in search of a non-system is a limited approach.

At a European Union level, influenced by the EU2020 headline target for early school leaving prevention of $10 \%$ across the EU, many recent European Commission and Council documents on early school leaving discuss 
system reform in terms of inclusive education. For example, the Council Conclusions 2015 on reducing early school leaving and promoting success in school explicitly refer to inclusive education as part of a focus on promoting development. The European Commission's Schools Policy Working Group Report 2015 on a whole school approach to early school leaving placed the framework of inclusive education centrally:

Policies to reduce early school leaving should be embedded in an overall inclusive learner-centred vision of education, in which high quality education is accessible to all. In such a vision, schools have a crucial role to play to ensure that all learners reach their full potential for growth irrespective of individual and family-related factors, socio-economic status and life experiences. Schools should be safe, welcoming and caring learning environments, striving for learners' engagement, in which children and young people can grow and develop as individuals and members of the community, feel respected and valued and recognised in their specific talents and needs. (p.8)

This Schools Policy Working Group report recognised 'the multi-faceted nature of the issue' $(2015, \mathrm{p} .8)$ that requires involvement of broader stakeholders than simply schools. They recommended a whole school approach that involves a systemic understanding, implicitly drawing on the ecological systemic approach of Bronfenbrenner (1979, 1995):

A 'whole school approach' is an ecological way of viewing a school. The school is seenas a multidimensional and interactive system that can learn and change. (p.8)

This approach has been further concretised in recent reports for the European Commission that seek to expand the framework of conceptualising inclusive systems in schools (Downes et al., 2016, 2017), as part of an emotional-relational focus on education systems to challenge the perceived neglect of emotional dimensions to early school leaving and inequality in education (Downes, 2010, 2011) by the OECD's ten steps to equity in education (2007). In doing so, these more recent perspectives on inclusive systems notably expandon the Council Recommendations on reducing early school leaving 2011. These Council Recommendations 2011, while referring to social exclusion and inclusive growth, and to social inclusion in the context of lifelong learning, did not explicitly adopt the terms inclusive education or inclusive systems in education ${ }^{2}$.

This article seeks to summarise key features of this emerging framework of inclusive systems in education, to identify the conceptual foundations and main features of this framework, with a particular focus on early school

2 It is notable that a focus on diversity, early school leaving and inclusive education is gaining increasing focus in Serbia, with recent publications such as Krstić et al. (2015), Friedman et al. (2015) and Kovač Cerović et al. (2016). 
leaving prevention. In doing so, the focus is on inclusive systems in and around schools. The examples to illustrate key thematic issues are necessarily selective rather than purporting to be a comprehensive review of each theme. While the framework has been developed predominantly in a European context, building on international research, it is an evolving one that is arguably of cross-cultural relevance, both as part of a rights-based argument in education systems and as part of a quality promotion focus to promote inclusive systems. At the outset, it is to be noted that the emphasis is less on seeking to prevent a problem, such as early school leaving or bullying in school, but rather to promote features of inclusive systems and in so doing, to address barriers and blockages at system level to this vision of system development.

\section{Conceptual Foundations of Systems and Inclusion}

Each of these three sections (a-c) addresses distinct, though strongly related, dimensions of inclusive systems. Section a) addresses system blockage aspects, section b) focuses more on promoting features of inclusion at system level, while section c) seeks system supports to overcome system fragmentation. In doing so, this framework seeks to overcome gaps in Bronfenbrenner's $(1979,1995)$ systems model.

\section{a) System Paradigm, System Blockage and Moving Beyond Resilient Systems}

Systemic understandings necessarily underpin conceptions of inclusive systems. Much of this systemic framework in educational, developmental and community psychology draws from well-known the social-ecological systems framework of Bronfenbrenner $(1979,1995)$. This is arguably the dominant paradigm for understanding systems in psychology. Bronfenbrenner (1979) distinguishes a range of different concentric nested system level interactions, ranging from micro relations in the immediate setting to meso-, exo- and macrosystem levels of 'generalised patterns' (p. 8). A mesosystem involves interrelations among two or more settings in which the developing person actively participates-for a child, home, school neighbourhood and peer group and, for an adult, family, work and social life (Bronfenbrenner, 1979, p. 25). An exosystem involves one or more settings that do not involve the developing person as an active participant, but in which events occur that affect or are affected by what happens in the setting containing the developing person (Bronfenbrenner 1979, p. 25). Key strengths of Bronfenbrenner (1979) include his focus on the need to examine: multiple levels rather than the individual decontextualised and in isolation, transitions, a two-way flow of reciprocal causality in systems, promoting growth in systems rather than being locked into deficits. His later work added the dimension of time, through the chronosystem (Bronfenbrenner, 1995), though this addition of a time dimension still offers only a limited understanding of system change and system inertia and resistance to such change (Downes, 2014). 
A focus on inclusive systems must address system exclusions. As well as structural poverty issues, these exclusions include power imbalances such as authoritarian teaching and discriminatory bullying. System blockages are neglected concerns in Bronfenbrenner's accounts (Downes, 2014). This proposed acceleration of focus on addressing blockages in systems also needs to recognise that Bronfenbrenner gives insufficient emphasis to systemic violence, whether physical, relational or symbolic, and the need to hear the voices of children, as well as of marginalised groups.

A related aspect of a systemic dimension to inclusive systems is to go beyond individualistic understandings of resilience in developmental psychology. The resilience framework seeks to improve on a framework of risk and protective factors through emphasising the active role of the individual in responding to these risk and protective factors. Ungar et al. (2007, p. 288) observe 'a shift in focus from individual characteristics to protective factors, and finally to health resources and assets in a child's community' that 'has taken place in mostly western contexts'.

Ungar broadens Rutter's $(1985,1987)$ conception of resilience to a socioecological model of resilience drawn from Bronfenbrenner:

In the context of exposure to significant adversity, whether psychological, environmental, or both, resilience is both the capacity of the individual to navigate their way to health-sustaining resources, including opportunities toexperience feelings of well-being, and a condition of the individual's family, community and culture to provide these health resources and experiences in culturally meaningful ways.(Ungar, 2008, p.225)

However, this broader environmental model that concerns itself with resilient systems does not include a focus on State systemic supports, such as integrated services (Edwards \& Downes, 2013) or developing inclusive systems of care as sought in community psychology (Cook \&Kilmer, 2012; Suarez et al., 2012). Ungar's (2012) systemic broadening of Rutter's resilience needs to go further in its systemic concerns to also include a focus on outreach to marginalised families (Downes, 2017), whether as individual or community outreach (Downes, 2014a). Framed as the capacity of the individual to navigate their way to environmental resources, this places the onus of accessibility onto the individual's efforts rather than a concern with responsive systems in suitably located settings that are culturally, physically and economically accessible to marginalised groups. Against this background, the concern with inclusive systems seeks to go beyond not only the well-established framework of individual resilience in developmental psychology, but also to go further than its expansion into resilient systems, as these tend to omit a focus on outreach and multidisciplinary teams as part of systems of care for integrated services.

A further argument for inclusive systems is that it is a deep structure as a primordial cross-cultural structure of space with regards to concentric spatial structures of relative inclusion and openness in dynamic tension 
with diametric spatial structures of relative exclusion and closure. This argument, building on a reinterpretation of the cross-cultural observations of Lévi-Strauss $(1963,1973)$ in structural anthropology, has been made in detail elsewhere with regard to inclusive systems in education (Downes, 2009, 2013, 2014, 2016, 2017) and at intrapsychic system (Downes, 2003, 2012) and neuropsychology levels (Downes, 2016a). It seeks to render dynamic the space of Bronfenbrenner's static concentric nested systems. This dynamism takes space through treating space as an active engaged background supporting condition affecting systems, rather than as a passive detached frame for understanding; space is envisaged as actively interacting with the system elements, as an element itself of the system, as a necessary or supportive condition for causal interactions in the system. Concentric and diametric spaces are understood as relational spaces. A further avenue for dynamism in this framework of concentric and diametric spatial systems is the compensatory relation between both spatial systems (Lévi-Strauss 1963; Downes 2012), where gain in one system brings a reduction in the other system in a particular domain. For example, increase in a concentric spatial system of assumed connection challenges diametric spatial systems of assumed separation, over a given systemic domain such as a school. The mutual interaction between concentric and diametric spatial systems provides a dynamism for systems as part of a focus on system change.

\section{b) Common principles for inclusion underpinning a framework of inclusive systems}

The recent report for the European Commission on structural indicators for inclusive systems (Downes et al., 2017) identifies ten key principles for inclusive systems, based on international research and law, as well as EU Policy documents. These include, inter alia, children's participation, equality and non-discrimination, a holistic focus on children's wider needs, parental involvement, lifelong learning, as well as recognition of the importance of a systemic approach.

Whereas students' voices are a clear gap in the EU Council and Commission documents (2011) on early school leaving prevention, this key principle is placed at the core of the EU Commission's Thematic Working Group on early school leaving report (2013):

Ensure children and young people are at the centre of all policies aimed at reducing ESL. Ensure their voices are taken into account when developing and implementing such policies.

This principle draws from international law, specifically, Article 12 (1)of the UN Convention on the Rights of the Child ratified by all EU member states, which declares:'States Parties shall assure to the child who is capable of forming his or her own views the right to express those views freely in all 
matters affecting the child, the views of the child being given due weight in accordance with the age and maturity of the child'. It is notable that children's voices are largely absent from US research in education, including for early school leaving prevention, as the USis an international exception as it has not ratified the UN Convention on the Rights of the Child.

The principle of equality and nondiscrimination for inclusive systems recognizes that substantive equality requires a commitment to educational success for everyone irrespective of social background and to achieve this, different groups may need additional supports. Non-discrimination includes a right to equality of concern and respect in a supportive environment free of prejudice. This principle raises a concern about discriminatory bullying by teachers, identified by Elamés (2013) European research. Elamés (2013) 10 country European study observes 'the fundamental importance' of teacher influence on discriminatory bullying: Those immigrant and Roma students who think the teacher exhibits similar behaviour towards 'native' and immigrant and Roma children in the class are those bullied least in the last 3 months. In contrast, those who declare that their teacher favours native children over immigrant/Roma students are more vulnerable to suffer some form of bullying. Specifically less than half (48 \%) of the 123 [immigrant/Roma] children across the 10 countries who sense bias in the teachers' attitudes towards native classmates declare to have never been subjected to violence (Elamé, 2013).

Equality of concern and respect also invites focus on the issue of authoritarian teaching as a risk factor for early school leaving and demotivation of students. The World Health Organisation's (2012) survey of student wellbeing observed the following needs for system development: Modifications that appear to have merit include establishing a caring atmosphere that promotes autonomy; providing positive feedback; not publicly humiliating students who perform poorly; identifying and promoting young people's special interests and skills to acknowledge that schools value the diversity they bring.

Downes' (2004) student centred research in Ballyfermot, an area of high socio-economic exclusion in Dublin, Ireland, involved 12 focus groups and 173 questionnaire responses from secondary students. Illustrative responses raising the central concern with authoritarian teaching approaches include as follows:

- "Have anger management courses for teachers" (female, focus group)

- "The teachers shouting at you. That makes me really, really down" (Age $13, \mathrm{~F})$

- "If the teachers didn't roar at you" (Age 13, F)

- "Have an equal teaching system and sack ignorant snobby teachers... very harsh teachers usually make me stay out of school" (Age 16, M)

The following response by a student in a subsequent study in Dublin (Downes\&Maunsell, 2007), "No, some[teachers] think they own the school", 
raises the important question of who actually owns the school, in order to challenge an assumption that teachers do so.A basic professional standard needs to be held by all teachers, cognisant of the basic principle, primum non nocere, first do no harm (Downes, 2013a); authoritarian teaching, ruling by fear and public humiliation (WHO, 2012), is harmful for students and increasing their risk of alienation and exclusion from the system through early school leaving. The principle of first do no harm pertains to a rightsbased focus on inclusive systems; the further injunction of the World Health Organisation to create a caring school climate raises the issues of quality promotion dimensions for inclusive systems.

It is important also to acknowledge that PISA findings do not simply focus on literacy and numeracy results but additionally examine the key dimension for inclusive systems of school climate. The following table reveals perceptions of socio-economically marginalised students of the inclusiveness or otherwise of the school climate, across a range of European contexts. While the scores on this dimension in France are of particular concern, Serbia is above the OECD average for feeling of belonging at school for this marginalised group, though below the OECD average for feeling like an outsider.

Table 1: Percentage of Socioeconomically Disadvantaged Students who Agree/Disagree with the Following Statements: School Belonging and Feeling Like an Outsider (PISA, 2012, Table III.2.3c, selected countries)

\begin{tabular}{|l|c|c|}
\multicolumn{1}{c|}{ Countries } & $\begin{array}{c}\text { I feel like I belong at school } \\
\text { \% S.E Agree }\end{array}$ & $\begin{array}{c}\text { I feel like an outsider } \\
\text { (or left out of things at school) } \\
\text { \% S.E. Disagree }\end{array}$ \\
\hline Belgium & $63.5(1.6)$ & $88.4(1.0)$ \\
\hline Czech Republic & $73.6(1.9)$ & $80.5(1.6)$ \\
\hline Denmark & $69.3(1.6)$ & $90.3(1.0)$ \\
\hline Estonia & $78.2(1.8)$ & $90.0(1.3)$ \\
\hline France & $38(1.7)$ & $73.2(1.8)$ \\
\hline Germany & $83.8(1.6)$ & $89.7(1.4)$ \\
\hline Greece & $87.8(1.2)$ & $83.9(1.4)$ \\
\hline Hungary & $83.5(1.1)$ & $85.6(1.6)$ \\
\hline Ireland & $76.7(1.5)$ & $91.6(1.0)$ \\
\hline Italy & $75(0.9)$ & $89.3(0.6)$ \\
\hline Luxembourg & $71.9(1.7)$ & $85.9(1.2)$ \\
\hline Poland & $73.2(1.8)$ & $88.2(1.3)$ \\
\hline Serbia & $86.4(1.2)$ & $83.1(1.5)$ \\
\hline Slovak Republic & $75.4(1.8)$ & $74.0(2.3)$ \\
\hline Slovenia & $83.7(1.7)$ & $89.0(1.2)$ \\
\hline Spain & $92.1(0.7)$ & $90.1(1.0)$ \\
\hline Sweden & $74.8(1.9)$ & $87.0(1.3)$ \\
\hline United Kingdom & $74.9(1.5)$ & $86.9(1.1)$ \\
\hline OECD Average & $78.1(0.3)$ & $86.2(0.2)$ \\
\hline
\end{tabular}


Commitment to a holistic approach recognises the social, emotional and physical (e.g., hunger, sleep deficits) needs, not simply the academic and cognitive needs, of both children/young people and their parents. A key and somewhat neglected feature of such holistic principles, applied to international research on parental involvement, is the need to adopt an integrated strategy for marginalised parents' health and education needs.In other words, parental involvement in education and family support dimensions for health, including mental health and wellbeing of families, requires a common integrated strategy. This involves a wider understanding of the systemic needsof marginalised parents than well-established and oft-cited conceptions of parentalinvolvement in education, such as that of Epstein (2001).

Epstein's research based 'Framework of Parental Involvement' identifies six ways in which schools and parents can be involved, i.e. Parenting, Communicating, Volunteering, Learning at home, Decision Making and Collaborating with the Community. Epstein has also identified challenges and redefinitions from traditional practice for all six of these areas based on her research, e.g. under the Communicating Strand, this is not just a one way stream of school to parent but a two way and sometimes maybe even a three way stream of dialogueand feedback between parent, school and community. Epstein and Sheldon (2006) proposed that school, family and community partnershipis a better term than parental involvement. However, there is a need to go further than this to encompass a health and family support focus. Epstein and Sheldon's (2006) emphasis on partnership is an important one with regard to challenging hierarchical systems and moving towards more democratic relational systems that give spaces for student and parental voices. Yet partnership is for Arnstein (1969) weaker than power delegation and citizen control, though stronger than placation and consultation. Epstein's focus is less tailored to the needs of the most vulnerable, often highly marginalised parents who experience high levels of stressful environmental factors due to livingin poverty. These poverty related stressors impact upon their health and wellbeing. Mental health issues, including depression, anxiety, disruptive behaviour and post-traumatic stress disorder, can negatively impact on a child's school success, as well as general wellbeing(World Health Organization, 2003; Kessler, 2009; Downes, 2011). Addressing these issues requires a family support focus integrated into school inclusion strategies, involving a child-centred approach to family support.

While commitment to a lifelong learning principle for inclusive systems may embrace issues such as active citizenship, personal and social fulfilment, as well as social inclusion and community development goals, an emerging issue here for current purposes is availability of the school site after school hours for lifelong learning courses for parents, whether based on non-formal or formal education. 
The 10 city European PREVENT project investigated this issue, from the perspective of parental involvement for early school leaving prevention (Downes, 2014a). The following table illustrates the high level of variation in practice on this issue across a range of European cities.

Table 2. Municipality Responses across Nine European Cities:

Availability of School Site after School Hours for

Lifelong Learning Classes for Parents (Downes, 2014a)

\begin{tabular}{|c|c|}
\hline Country & $\begin{array}{l}\text { On a scale of 1-3 where } 3 \text { means at least } 80 \% \text { of schools in your } \\
\text { municipality open their doors after school hours for lifelong } \\
\text { learning classes and } 2 \text { means at least } 30 \% \text { of schools do so and } 1 \\
\text { means less than } 30 \% \text { of schools do so - which number best } \\
\text { describes the situation in your municipality? }\end{array}$ \\
\hline The Hague & 3 \\
\hline Gijon & 3 \\
\hline Tallinn & 2 \\
\hline Stockholm & 2 \\
\hline Antwerp & 1 \\
\hline Usti & 1 \\
\hline Munich & 1 \\
\hline Nantes & 1 \\
\hline Sofia & 1 \\
\hline
\end{tabular}

Opening the school after school hours can make the school a lifelong learning community and a focal point for community education. This may be a key resource in areas of high socio-economic exclusion and play an important role in promoting inclusive systems and early school leaving prevention.

As well as these key principles for inclusive systems - children's participation, equality and non-discrimination, holistic approach bridging health and education, parental involvement, lifelong learning, as well as a systemic approach - other key principles identified in the NESET report for the Commission (Downes et al., 2017) are differentiation in prevention approaches, multidisciplinarity as a multifaceted response for students with complex needs, building on strengths and representation and participation of marginalised groups. Some of these aspects are of relevance to establishing common systems of supports for inclusion.

Common systems of supports for inclusion and to address system fragmentation

System fragmentation is a neglected feature in Bronfenbrenner's accounts (Downes, 2014), while the increasing interest in analysing systems of care in community psychology (Cook \&Kilmer, 2012; Suarez et al., 2012) reveals a 
frequent concern to address issues of inertia and fragmentation. An important aspect of a framework of inclusive systems overcoming fragmentation is that problems that may be treated as largely distinct when viewed from the perspective of individuals may be addressed through common supports when examined with a systemic lens. An example of this is growing recognition of the range of interconnected issues for bullying and early school leaving. An illustrative study on this is that of Cornell et al. (2013) which found that risk of early school leaving increases if a student experiences an atmosphere of teasing and bullying even if s/he is not personally bullied.In a sample of 276 high schools, the level of teasing and bullying reported by both ninthgrade students and teachers was predictive of cumulative dropout counts over 4 years after the cohort reached the $12^{\text {th }}$ grade. A basic conclusion from Cornell et al's (2013) study is that the prevalence of teasing and bullying in high schools deserves serious consideration by educators in addressing the problem of early school leaving. Cornell et al. (2013) conclude that "Because educators are often concerned about the impact of student poverty and academic capability on dropout rates in their schools, these findings suggest that a climate of teasing and bullying in the school also deserves consideration. Notably, the increased dropout count that was associated with Prevalence of Teasing and Bullying was quite similar to the increases that were associated with FRPM [i.e., poverty] and academic failure". Cornell et al. (2013) seek, in effect, a stronger systemic focus on school climate through their conclusion that early school leaving programs often focus too narrowly on changes in individual students, without considering broader peer and school influences.

A recent review for the European Commission (Downes \& Cefai, 2016) goes further to argue that a range of recommended supports in international research and EU Council and Commission documents for early school leaving prevention are also directly relevant to bullying prevention. It highlights direct and indirect effects of bullying on early school leaving relevant to perpetrators, victims and bully-victims, such as school absence, negative interpersonal relations with peers and conflict with teachers, lowconcentration in school, decreased academic performance, negative school climate influences,lower school belonging, satisfaction, andpedagogical wellbeing, with the effects of bullying exacerbated for those already at risk of early school leaving. It proposes common systems of supports to address both issues, such as a transition focus from primary to post-primary school, multiprofessional teams forcomplex needs, language support needs, family support services and education of parents regarding their approaches to communication and supportive discipline with their children, outreach to families to provide supports, and addressing academic difficulties. Downes and Cefai (2016) highlight common issues requiring an integrated strategic response, including the prevention of displacement effectsof a problem from 
one domain to another, such as in suspension/expulsion, which may make a bullying problem become an early school leaving problem. This report also points to common causal antecedents for early school leaving and bullying, such as negative school climate, behavioural difficulties, and trauma.School bullying prevention can be conceptualised as one dimension of positive school climate promotion. The argument in this report for a commonality of system-level response for both bullying and early school leaving prevention is not to state that the same individuals are necessarily at risk for both, though they may share a number of common risk factors.

Building on these insights, a subsequent recent report for the Commission (Downes et al., 2017) seeks to develop a cluster of interrelated themes into a common domain of inclusive systems in and around schools. Such inclusive systems place a strong emphasis on supportive, quality learning environments, and welcoming and caring schools and classrooms:

It addresses the needs of students in a holistic way (their emotional,physical, cognitive and social needs), and recognises their individual talents and voices. It seeks toprevent discrimination, and is open to the voices and active participation of parents and wider multidisciplinary teams and agencies. Inclusive systems in and around schools especially prioritise the differentiated needs of marginalised and vulnerable groups, including those at risk of early school leaving and alienation from society (Downes et al., 2017, p.15)

The term 'in and around schools' refers to the need for inclusive systems to engage with multidisciplinary teams and interagency working as part of a whole school approach (Edwards \&Downes, 2013; Commission TWG on Early School Leaving, 2013; Commission School Policy WG on Early School Leaving, 2015). This builds on the need to address system fragmentation and to overcome local level power relations between services bringing territoriality. Local rivalries across municipalities and schools pose an obstacle to sharing of good practice. It recognises that there may be local rivalries across agencies especially in a recession - to claim resources and credit for gains.

The Alliances for Inclusion report (Edwards \&Downes, 2013) for the European Commission identified 16 examples of cross-sectoral cooperation from 10 European countries, with a particular focus on early school leaving prevention. This report observes that a policy focus is needed to go beyond multiple agencies, with a need to minimise fragmentation across diverse services 'passing on bits of the child' and family (Edwards \&Downes, 2013). It recognises that the multi-faceted nature of risk requires a multi-faceted response that needs to go beyond referrals to disparate services resulting in 'passing on bits of the child'. For genuine interprofessional collaboration for early school leaving prevention, for example, between schools and multidisciplinary teams of outreach care workers, therapists/counsellors, 
nurses, speech and language therapists, social workers, occupational therapists, policy-led co-location is not sufficient. Efforts are needed to support inter-professional collaborations and overcome resistance, with a need to focus on direct delivery and to minimise 'committee sitting'. As part of developing inclusive systems, each family experiencing marginalisation needs one 'lead professional' to link them with others (Edwards \& Downes, 2013a) rather than a proliferation of fragmented services that are not in communication with each other or do not have a team based approach to provision of supports.

Multidisciplinary teams in and around schools can offer a both/and model for both school based services where appropriate and local community based services, while offering scope for team members to move across various school locations (Downes, 2004). The well established model of differentiated needs (see Figure 1), highlights a focus on indicated prevention for intensive, individual supports, whether for an individual child or family.

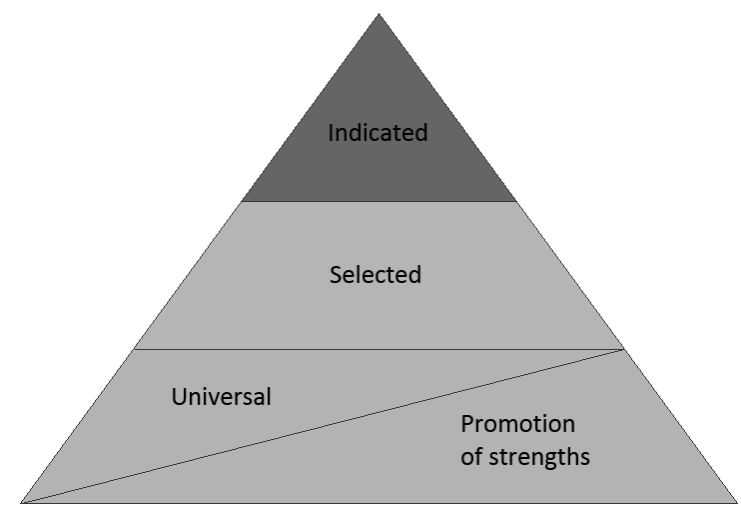

Figure 1.Differentiated Levels of Need for Prevention

This is the main level of strategic focus for multidisciplinary teams to address complex chronic needs of children and families. Other levels such as selected prevention for children and families experiencing moderate needs and risk, invite more group focused supports.

\section{Conclusion}

This article has sought to outline some of the key conceptual features underpinning the emerging concept of inclusive systems in and around schools, especially in a European Union context for early school leaving prevention. It has by no means been argued that the issues identified in this 
article are the sole concerns for developing inclusive systems. Key principles have been identified for inclusive systems and their relevance has been highlighted for issues of early school leaving prevention, such as prevention of authoritarian teaching and discriminatory bullying, integrating family support and parental involvement strategies, opening school buildings after school hours to make the school a focal point for lifelong learning and giving expression to students' voices.

A reconceptualisation of systemic understanding has been proposed to address neglected dimensions of system blockages, fragmentation and power imbalances in current understandings of systems theory in developmental, educational and community psychology. Furthermore, resilience theory has been reconstructed in systemic terms, embracing outreach and multidisciplinary teams as part of systems of care, to shift towards this emerging paradigm of inclusive systems in and around schools.

\section{References}

Arnstein, S.R.(1969). A ladder of citizen participation. Journal of the American Planning Association, 35 (4), 216-224.

Bronfenbrenner, U. (1979). The Ecology of Human Development. Boston: Harvard University Press.

Bronfenbrenner, U. (1995). Developmental ecology through space and time: A future perspective. In P. Moen \& G. H. Elder, Jr., (Eds.), Examining lives in context: Perspectives on the ecology of human development (pp. 619-647). Washington, DC: American Psychological Association.

Cook, J. R.\& Kilmer, R. P. (2012). Systems of care: New partnerships for community psychology. American Journal of Community Psychology, 49, 393-403.

Cornell, F., Gregory, A., Huang, F.\& Fan, X. (2013). Perceived Prevalence of Teasing and Bullying Predicts High School Dropout Rates. Journal of Educational Psychology, 105(1), 138-149.

Downes, P. (2003). Cross-cultural structures of concentric and diametric dualism in Lévi-Strauss' structural anthropology: Structures of relation underlying the self and ego relation? Journal of Analytical Psychology, 48 (1), 47-81.

Downes, P. (2004) Psychological support services for Ballyfermot: Present and future. Ballyfermot:URBAN

Downes, P. (2009). Prevention of Bullying at a Systemic Level in Schools: Movement from Cognitive and Spatial Narratives of Diametric Opposition to Concentric Relation. In S.R. Jimerson, S.M. Swearer, \&D.L. Espelage (Eds.), Handbook of Bullying in Schools: An International Perspective (pp.517-533). New York: Routledge.

Downes, P. (2010). 'It's the heart, stupid'. Emerging priority issues for prevention of early school leaving: A solution-focused approach.Invited presentation, the Belgian EUPresidency Conference, Breaking the cycle of disadvantage - Social inclusion in and through education, September 28 and 29, 2010, University of Ghent, Belgium. 
Downes, P. (2011). The neglected shadow: Some European perspectives on emotional supports for early school leaving prevention. International Journal of Emotional Education, 3 (2), 3-39.

Downes, P. (2012). The Primordial Dance: Diametric and Concentric Spaces in the Unconscious World. Oxford/Bern: Peter Lang.

Downes, P. (2013). Developing a framework and agenda for students' voices in theschool system across Europe: From diametric to concentric relational spaces for early school leaving prevention. European Journal of Education, Special Issue: Problematising the Issue of Early School Leaving in the European Context, 48 (3), 346-362.

Downes, P. (2013a). A holistic approach to early school leaving prevention in Europe: Key strategic priorities for system level development.Keynote opening presentation, European Network of Education Councils (EUNEC) conference on Early School Leaving, in conjunction with the European Commission and the Lithuanian Government (Ministry of Education and Science) in the context of its EU Presidency.Lithuanian Parliament (Seimas), Vilnius, November 18, 2013.

Downes, P. (2014). Access to Education in Europe: A framework and agenda for system change. Dordrecht: SpringerVerlag.

Downes, P. (2014a).Towards a Differentiated, Holistic and Systemic Approach to Parental Involvement in Europe for Early School Leaving Prevention. European Union, European Regional Development Fund, Urbact Secretariat, Paris.

Downes, P. (2016). Developing a framework of system change between diametric and concentric spaces for early school leaving prevention. Educational Philosophy and Theory, 48 (9), 899-914.

Downes, P. (2016a). Concentric and diametric spatial structures of relation: Exploring a neutral bridge language between quantum physics and neuropsychology. Neuroquantology, AnInterdisciplinary Journal of Neuroscience and Quantum Physics, 14 (3),619-629. doi: 10.14704/nq.2016.14.3.885

Downes, P. (2017). Reconceptualising foundational assumptions of resilience: A cross-cultural, spatial systems domain of relevance for agency and phenomenology in resilience. InternationalJournal of Emotional Education, 9 (1), 99-120.

Downes, P. \& Maunsell, C. (2007). Count us in: Tackling early school leaving in South West Inner City Dublin, An integrated response. Dublin: South Inner City Community Development Association (SICCDA) \& South Inner City Drugs Task Force.

Downes, P.,\&Cefai, C. (2016).How to tackle bullying and prevent school violence in EuropeEvidence and practices for strategies for inclusive and safe schools. Luxembourg: Publications Office of the European Union.

Downes, P., Nairz-Wirth, E.,\& Rusinaite, V. (2017).Structural Indicators for Developing Inclusive Systems in and around Schools in Europe. Luxembourg: Publications Office of the European Union.

Edwards, A.,\& Downes, P. (2013). Alliances for Inclusion: Developing Cross-sector Synergies and Inter-Professional Collaboration in and around Education. Commissioned Research Report for EU Commission NESET (Network of Experts on Social Aspects of Education and Training). 
Elamé, E. (2013). Discriminatory bullying: A new intercultural dialogue. Berlin: Springer Verlag.

Epstein, J.L., Sanders, M.G., Simon, B.S., Salinas, K.C., Jansorn, N.R.,\&Voorhis, F.L. (2001). School, Family, and Community Partnerships: Your Handbook for Action ( $2^{\text {nd }}$ edition). Thousand Oaks, CA: Corwin.

Epstein, J.L.,\& Sheldon, S.B (2006). Moving Forward: Ideas for Research on School, Family, and Community Partnerships.In C. F. Conrad \& R. Serlin (Eds.),SAGE Handbook for research in education: Engaging ideas and enriching inquiry. Thousand Oaks, CA: Sage Publications.

European Commission Staff Working Paper, Reducing Early School Leaving, Accompanying document to the Proposal for a Council Recommendation on policies to reduce Early School Leaving, 26th January 2011.https://publications.europa. eu/en/publication-detail/-/publication/1727c557-8ffa-4d80-8bc9-dc0feff6d836/ language-en

European Commission Communication to the European Parliament, the Council, the European Economic and Social Committee and the committee of the regions, Tackling Early School Leaving: A key contribution to the Europe 2020 Agenda, 31st January 2011.http://eur-lex.europa.eu/legal-content/EN/ ALL/?uri=celex:52011DC0018

European Commission (2013). Reducing early school leaving: Key messages and policy support. Final Reportof the Thematic Working Group on Early School Leaving.

European Commission (2015). Education \& Training 2020Schools policy: A whole school approach to tackling early school leaving: Policy messages. Brussels European Commission DG Education and Culture http://ec.europa.eu/education/policy/strategic-framework/expert-groups/documents/early-leaving-policy_en.pdf

EU COUNCIL, Council Recommendation on policies to reduce early school leaving COM (2011)19 finalSEC (2011) 98 final SEC(2011) 97 final SEC(2011) 96 final.

EU COUNCIL, Council Conclusions of 23 November 2015 on reducing early school leaving and promotingsuccess in school (14441/15).http://data.consilium.europa.eu/doc/document/ST-14441-2015-INIT/en/pdf

Faure, E., Herrera, F., Kaddoura, A.R., Lopes, H., Petrovsky, A.V., Rahnema, M.,\&Champion Ward, F. (1972).Learning to be: The world of education today and tomorrow. Paris: UNESCO.

Friedman, E., Pavlović Babić, D.\&Simić, N. (2015). Inclusive Education in Serbia Policies, Practice, and Recommendations. Beograd: The World Bank, Ministarstvo prosvete, nauke i tehnološkog razvoja Republike Srbije, Western Balkans Investment Framework.

Illich, I. (1971). Deschooling society. New York: Harper and Row.

Kessler, R. (2009). Identifying and screening for psychological and comorbid medical and psychological disorders in medical settings. Journal of Clinical Psycho$\log y, 65(3), 253-267$.

Kovač Cerović, T.,PavlovićBabić, D., Jokić, T., Jovanović, O., Jovanović, V.(2016). First Comprehensive Monitoring of Inclusive Education in Serbia: Selected Findings. In Gutvajn, N. \&Vujačić, M. (eds), Challenges and Perspectives of Inclusive Education. (pp.15-30). Belgrade: Institute for Educational Research. 
Krstić, K., Lazarević, Lj.\&StepanovićIlić, I. (2016). Dropout as A Result of Education With No Space for Diversity. In: A. Surian (ed) Open Spaces for Interaction and Learning Diversities(pp. 129-136). SensePublishers.

Kyriazopoulou, M. \&Weber, H. (editors) (2009). Development of a set of indicators - for inclusive education in Europe. Odense, Denmark: European Agency for Development in Special Needs Education.

Lévi-Strauss, C. (1963). Structural anthropology: Vol. 1. Trans. C. Jacobsen \& B. Grundfest Schoepf. Allen Lane: Penguin.

Lévi-Strauss, C. (1973). Structural anthropology: Vol. 2. Trans. M. Layton, 1977. Allen Lane: Penguin Books.

OECD (2007). Ten Steps to Equity in Education, OECD Publishing, Paris.

OECD, PISA (Programme for International Student Assessment) Results, OECD, Paris, 2012. http://www.oecd.org/pisa/keyfindings/pisa-2012-results.htm

Rutter, M. (1985). Resilience in the face of adversity. British Journal of Psychiatry, 147, 598-611.

Rutter, M. (1987). Psychosocial resilience and protective mechanisms.American Journal of Orthopsychiatry, 57, 316-331.

Suarez, L. M., Belcher, H.M.E., Briggs E.C.\& Titus, J.C. (2012). Supporting the need for an integrated system of care for youth with co-occurring traumatic stress and substance abuse problems. American Journal of Community Psychology, 49 (3-4), 430-440.

UNESCO (2016). 'Reaching out to all learners: A resource pack for supporting inclusive education.Geneva: UNESCO International Bureau of Education.

Ungar, M. (2012). The Social Ecology of Resilience: A Handbook of Theory and Practice. New York: Springer.

Ungar, M., Brown, M., Liebenberg, L., Othman, R., Kwong, W.M., Armstrong, M. \& Gilgun, J. (2007). Unique pathways to resilience across cultures. Adolescence, Vol. 42, No. 166, 287-310.

World Health Organization WHO (2003).Caring for children and adolescents with mental health disorders: setting WHO directions. Geneva, Switzerland: WHO.

World Health Organisation WHO (2012). Social determinants of health and well-being among young people. Health Behaviour in School-Aged Children (HBSC) Study: International Report from the 2009/2010 Survey. Copenhagen, Denmark: WHO. 


\section{Konceptualne osnove inkluzivnih sistema u školama i izvan njih za prevenciju ranog napuštanja škole: Emocionalno-relacioni fokus}

\section{Pol Dauns}

Institut za obrazovanje, Dablin Siti Univerzitet

Imajući u vidu jedan od glavnih ciljeva strategije Evropa 2020 koji se odnosi na smanjenje stope ranog napuštanja škole na $10 \%$ u evropskim zemljama, ovaj rad bavi se konceptualnim osnovama shvatanja inkluzivnih sistema za prevenciju ranog napuštanja škole koja su se poslednjih godina pojavila u strateškim dokumentima Evropske unije i različitim izveštajima o istraživanjima. U tradicionalnom smislu, inkluzivno obrazovanje podrazumeva fokus na decu sa posebnim obrazovnim potrebama. Međutim, u ovom konceptualnom pregledu, bavimo se time kako se inkluzija sve više posmatra u širim okvirima. U radu se stoga nastoji da se kritički rekonstruišu fundamentalna gledišta o sistemima i rezilijentnosti u razvojnoj i pedagoškoj psihologiji. Sistemski fokus u inkluziji treba da se pozabavi zanemarivanjem sistemskih prepreka i neravnomerne raspodele moći u psihologiji. Rezilijentnost se obično definiše kao kapacitet pojedinca da pronađe svoj put do resursa sredine. Ovim se problem pristupa resursima prebacuje na napore pojedinca, a ne na sisteme podrške koji su na raspolaganju marginalizovanim grupama. Bavljenje inkluzivnim sistemima prevazilazi ne samo dobro utemeljeni okvir individualne rezilijentnosti u razvojnoj psihologiji već i njegovo proširenje na rezilijentne sisteme jer se u njima ne uvažava značaj multidisciplinarnih timovima za podršku u sistemima integrisanih usluga. Zajednički principi za uspostavljanje osnova inkluzivnih sistema obuhvataju uvažavanje glasa dece, jednakost i nediskriminaciju, uključivanje roditelja koje se holistički integriše sa podrškom porodice i principe celoživotnog učenja za škole. U radu se ističu ilustrativni primeri ovih principa za reformu autoritarne nastave i sprečavanje diskriminatornog zlostavljanja, za otvaranje škola prema lokalnim zajednicama i za usmeravanje ka onima sa najvišim nivoom potreba.

Ključne reči: inkluzivni sistemi, rano napuštanje škole, rezilijentnost, zlostavljanje 